\title{
Pentafluorophenylammonium triflate (PFPAT): A new organocatalyst for the one-pot three-component synthesis of $\alpha$-aminophosphonates
}

\author{
FATEMEH MALAMIRI and SAMAD KHAKSAR* \\ Department of Chemistry, Ayatollah Amoli Branch, Islamic Azad University, PO Box 678, Amol, Iran \\ e-mail: s.khaksar@iauamol.ac.ir; Samadkhaksar@yahoo.com
}

MS received 8 November 2013; revised 29 January 2014; accepted 4 February 2014

\begin{abstract}
In the presence of a catalytic amount of pentafluorophenylammonium triflate (10 mol \%), dimethyl phosphite reacts with imines (generated in situ from aldehydes and amines) to yield the corresponding coupling products in good yield. The organocatalyst is air-stable, cost-effective, easy to handle, and easily removed from the reaction mixtures.
\end{abstract}

Keywords. $\quad \alpha$-Amino phosphonates; nucleophilic addition; Kabachnik-Fields reaction; organocatalyst.

\section{Introduction}

Owing to their pharmacological and medicinal importance, ${ }^{1}$ synthesis of $\alpha$-aminophosphonates, the structural analogues of $\alpha$-amino acids, has received increased attention during the last two decades. Their potential as peptidomimetics, ${ }^{2}$ enzyme inhibitors ${ }^{3-5}$ including HIV protease, ${ }^{6,7}$ herbicides,${ }^{8}$ insecticides, ${ }^{9}$ fungicides, ${ }^{10}$ and antiviral agents, ${ }^{11}$ as well as their role for antibody generation ${ }^{12}$ is well-documented. Of the variety of reported methods ${ }^{13-20}$ for the synthesis of $\alpha$-aminophosphonates, most are based on nucleophilic addition of phosphates to iminecatalysed base, ${ }^{21}$ protic, ${ }^{22}$ or Lewis acids such as aluminium(III) chloride, ${ }^{23}$ zirconium(IV) chloride, ${ }^{24}$ zinc(II) chloride, ${ }^{25}$ and boron trifluoride-diethyl ether complex. ${ }^{26}$ However, these reactions cannot be carried out in a one-step operation because the amines and water that exist during imine formation can decompose or deactivate the Lewis acids. In recent years, several new efficient methods have been developed including the use of $\mathrm{H}_{3} \mathrm{PW}_{12} \mathrm{O}_{40},{ }^{27}$ magnesium percholorate, ${ }^{28}$ $\mathrm{PhNMe}_{3} \mathrm{Cl},{ }^{29}$ bismuth nitrate pentahydrate, ${ }^{30}$ scandium tris (dodecyl sulphate), ${ }^{31}$ indium(III) chloride, ${ }^{32}$ metal triflates $[\mathrm{M}(\mathrm{OTf}) \mathrm{n}, \mathrm{M}=\mathrm{La}, \mathrm{Li}, \mathrm{Mg}, \mathrm{Al}, \mathrm{Cu}$, $\mathrm{Ce}],{ }^{33} \mathrm{LiClO}_{4},{ }^{34} \mathrm{Al}_{2} \mathrm{O}_{3},{ }^{35} \mathrm{CF}_{3} \mathrm{CO}_{2} \mathrm{H},{ }^{36}$ montmorillonite $\mathrm{KSF}^{37}$ (bromodimethyl) sulphonium bromide, ${ }^{38}$ lanthanide triflate, ${ }^{39} \mathrm{InCl}_{3},{ }^{40} \mathrm{TaCl}_{5}-\mathrm{SiO}_{2},{ }^{41}$ oxalic acid, ${ }^{42}$ trifluoroethanol ${ }^{43}$ and succinic acid. ${ }^{44}$ These methods show varying degrees of success as well as limitations such as harsh reaction conditions, expensive and detrimental metal reagents, tedious work-up, low product

\footnotetext{
*For correspondence
}

yields, long reaction times, and co-occurrence of several side products. Therefore, a simple, efficient method for the synthesis of $\alpha$-aminophosphonates remains an attractive goal.

In recent years, increasing attention has been paid to organocatalysts due to economic and environmental considerations. ${ }^{45-48}$ Organocatalysts have received extensive recognitions in organic synthesis due to its unique properties of being readily affordable, selectivity, longer catalyst life, negligible equipment corrosion, ease of product separation, nontoxic and reusability. Of these, pentafluorophenylammonium triflate (PFPAT) has emerged as a powerful Brønsted acid catalyst to perform many useful organic transformations ${ }^{49-57}$ under mild reaction conditions. Due to the current challenges for developing environmentally benign synthetic processes and in continuation of our interest in the application of new organocatalysts for various organic transformations, ${ }^{52-57}$ we report an efficient route for the synthesis of $\alpha$-aminophosphonate derivatives using PFPAT as a catalyst (scheme 1).

\section{Experimental}

\subsection{Apparatus and analysis}

NMR spectra were determined on an FT-NMR Bruker $\mathrm{AV}-400$ spectrometer in $\mathrm{CDCl}_{3}$ or DMSO- $d_{6}$ and are expressed in $\delta$ values relative to tetramethylsilane; coupling constants $(J)$ are measured in Hertz. Melting points were determined on an Electrothermal 9100 apparatus. Infrared spectra were recorded on a Rayleigh WQF-510 Fourier transform instrument. Commercially 


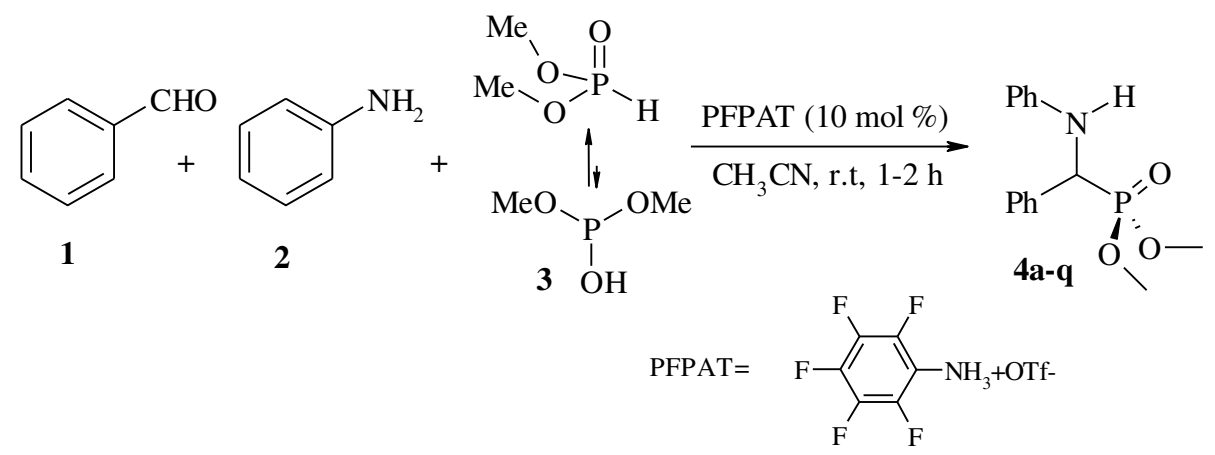

Scheme 1. Synthesis of $\alpha$-aminophosphonates 4 from various aldehydes and amines.

available reagents were used throughout without further purification.

\subsection{General procedure for the synthesis of $\alpha$-amino- phosphonate derivatives}

A mixture of amine $(1 \mathrm{mmol})$, aldehyde $(1 \mathrm{mmol})$, and dimethyl phosphite $(1 \mathrm{mmol})$ dissolved in $3 \mathrm{~mL}$ toluene, and PFPAT (10 mol\%) was stirred for $1 \mathrm{~h}$ at room temperature. The reaction was monitored by TLC. The reaction mixture, after being cooled to room temperature was poured onto crushed ice and stirred for 5$10 \mathrm{~min}$. The crystalline product was collected by filtration under suction (water aspirator), washed with icecold water $(40 \mathrm{ml})$ and then recrystallized from hot ethanol to afford pure products. Products were characterized by comparison of their physical and spectral data with those of authentic samples. ${ }^{27}$ Spectroscopic data for selected examples are shown here.

\subsection{Spectroscopic data for selected examples}

Compound (4a): White solid, mp $87^{\circ} \mathrm{C}$; $1 \mathrm{H}$ NMR $\left(400 \mathrm{MHz}, \mathrm{CDCl}_{3}\right): \delta=3.51(\mathrm{~d}, J=10.5 \mathrm{~Hz}, 3 \mathrm{H})$, $3.81(\mathrm{~d}, J=10.6 \mathrm{~Hz}, 3 \mathrm{H}), 4.82(\mathrm{~d}, J=24 \mathrm{~Hz}, 1 \mathrm{H})$, 4.84 (br s, 1H), $6.64(\mathrm{~d}, J=8.0 \mathrm{~Hz}, 2 \mathrm{H}), 6.74(\mathrm{t}, J=$ $7.2 \mathrm{~Hz}, 1 \mathrm{H}), 7.1(\mathrm{t}, J=7.7 \mathrm{~Hz}, 2 \mathrm{H}), 7.3(\mathrm{t}, J=7.5 \mathrm{~Hz}$, $1 \mathrm{H}), 7.39(\mathrm{t}, J=7.4 \mathrm{~Hz}, 2 \mathrm{H}), 7.5(\mathrm{~d}, J=7.3 \mathrm{~Hz}, 2 \mathrm{H})$; ${ }^{13} \mathrm{C}$ NMR $\left(100 \mathrm{MHz}, \mathrm{CDCl}_{3}\right): \delta=54.1\left(\mathrm{~d},{ }^{2} J_{\mathrm{p}-\mathrm{c}}=\right.$ $\left.7.0 \mathrm{~Hz}, \mathrm{OCH}_{3}\right), 54.2\left({ }^{2} J_{\mathrm{p}-\mathrm{c}}=6.8 \mathrm{~Hz}, \mathrm{OCH}_{3}\right), 56.2(\mathrm{~d}$, $\left.{ }^{1} J_{\mathrm{p}-\mathrm{c}}=150 \mathrm{~Hz}, \mathrm{CH}\right), 68.5(\mathrm{CH}), 114.3(\mathrm{CH}), 119.0$ $(\mathrm{CH}), 128.2\left(\mathrm{~d},{ }^{3} J_{\mathrm{p}-\mathrm{c}}=5.8 \mathrm{~Hz}, \mathrm{CH}\right), 128.4\left(\mathrm{~d},{ }^{3} J_{\mathrm{p}-\mathrm{c}}=\right.$ $3.1 \mathrm{~Hz}, \mathrm{CH}), 129.1(\mathrm{CH}), 131.2(\mathrm{CH}), 136.0(\mathrm{C}), 146.6$ $\left(\mathrm{d},{ }^{2} J_{\mathrm{p}-\mathrm{c}}=14.5 \mathrm{~Hz}, \mathrm{C}\right)$.

Compound (4b): White solid, mp $60{ }^{\circ} \mathrm{C} ;{ }^{1} \mathrm{H}$ NMR $\left(400 \mathrm{MHz}, \mathrm{CDCl}_{3}\right): \delta=3.51(\mathrm{~m}, 1 \mathrm{H}), 3.79(\mathrm{~d}, J=$ $11.8 \mathrm{~Hz}, 3 \mathrm{H}), 3.83(\mathrm{~d}, J=10.1 \mathrm{~Hz}, 3 \mathrm{H}), 5.2(\mathrm{~d}, J=$ $24 \mathrm{~Hz}, 1 \mathrm{H}), 6.8-7.28(\mathrm{~m}, 5 \mathrm{H}), 7.3(\mathrm{~d}, J=8.5 \mathrm{~Hz}$, $2 \mathrm{H}), 7.5(\mathrm{~d}, J=8.5 \mathrm{~Hz}, 2 \mathrm{H}) ;{ }^{13} \mathrm{C} \mathrm{NMR}(100 \mathrm{MHz}$, $\left.\mathrm{CDCl}_{3}\right): \delta=56.1\left(\mathrm{~d},{ }^{2} J_{\mathrm{p}-\mathrm{c}}=7.0 \mathrm{~Hz}, \mathrm{OCH}_{3}\right), 56.2(\mathrm{~d}$, $\left.{ }^{2} J_{\mathrm{p}-\mathrm{c}}=6.8 \mathrm{~Hz}, \mathrm{OCH}_{3}\right), 57.2\left(\mathrm{~d},{ }^{1} J_{\mathrm{p}-\mathrm{c}}=150 \mathrm{~Hz}, \mathrm{CH}\right)$, $114.3(\mathrm{CH}), 120.0(\mathrm{CH}), 128.2\left(\mathrm{~d},{ }^{3} J_{\mathrm{p}-\mathrm{c}}=5.8 \mathrm{~Hz}, \mathrm{CH}\right)$, $128.4\left(\mathrm{~d},{ }^{3} J_{\mathrm{p}-\mathrm{c}}=3.1 \mathrm{~Hz}, \mathrm{CH}\right), 130.1(\mathrm{CH}), 131.2(\mathrm{C})$, $140.0(\mathrm{C}), 146.6\left(\mathrm{~d},{ }^{2} J_{\mathrm{p}-\mathrm{c}}=14.5 \mathrm{~Hz}, \mathrm{C}\right)$.

Compound (4e): Viscous yellowish oil; ${ }^{1} \mathrm{H}$ NMR $\left(400 \mathrm{MHz}, \mathrm{CDCl}_{3}\right): \delta=3.6(\mathrm{~d}, \mathrm{~J}=10.6 \mathrm{~Hz}, 3 \mathrm{H})$, $3.8(\mathrm{~d}, J=10.6 \mathrm{~Hz}, 3 \mathrm{H}), 4.5($ br s, $1 \mathrm{H}), 5.0(\mathrm{~d}, J=$ $23.8 \mathrm{~Hz}, 1 \mathrm{H}), 6.37-7.40(\mathrm{~m}, 8 \mathrm{H}) ;{ }^{13} \mathrm{C} \mathrm{NMR}(100 \mathrm{MHz}$, $\left.\mathrm{CDCl}_{3}\right): \delta=50\left(\mathrm{~d},{ }^{1} J_{\mathrm{p}-\mathrm{c}}=159.6 \mathrm{~Hz}, \mathrm{CH}\right), 54.1$ $\left(\mathrm{d},{ }^{2} J_{\mathrm{p}-\mathrm{c}}=5.8 \mathrm{~Hz}, \mathrm{OCH}_{3}\right), 54.4\left(\mathrm{~d},{ }^{2} J_{\mathrm{p}-\mathrm{c}}=6.9 \mathrm{~Hz}\right.$, $\left.\mathrm{OCH}_{3}\right), 109.4\left(\mathrm{~d},{ }^{3} \mathrm{~J}_{\mathrm{p}-\mathrm{c}}=6.8 \mathrm{~Hz}, \mathrm{CH}\right), 111.2(\mathrm{CH})$, $114.4(\mathrm{CH}), 119.5(\mathrm{CH}), 129.9\left(\mathrm{~d},{ }^{3} \mathrm{~J}_{\mathrm{p}-\mathrm{c}}=5.6 \mathrm{~Hz}, \mathrm{CH}\right)$, $143.1(\mathrm{CH}), 146.3\left(\mathrm{~d},{ }^{2} \mathrm{~J}_{\mathrm{p}-\mathrm{c}}=13.3 \mathrm{~Hz}, \mathrm{C}\right), 149.4(\mathrm{C})$.

Compound (4k): Viscous yellowish oil; ${ }^{1} \mathrm{H}$ NMR $\left(400 \mathrm{MHz}, \mathrm{CDCl}_{3}\right): \delta=3.49(\mathrm{~d}, 3 \mathrm{H}, J=10.5 \mathrm{~Hz})$, $3.71(\mathrm{~d}, 3 \mathrm{H}, J=10.6 \mathrm{~Hz}), 4.71-4.79\left(\mathrm{~d}, 1 \mathrm{H},{ }^{1} J_{\mathrm{P}-\mathrm{H}}=\right.$ $23.9 \mathrm{~Hz}), 6.5-7.25(\mathrm{~m}, 9 \mathrm{H}) ;{ }^{13} \mathrm{C} \mathrm{NMR}(100 \mathrm{MHz}$, $\left.\mathrm{CDCl}_{3}\right): \delta=51.9(\mathrm{CH}), 54.03\left(\mathrm{OCH}_{3}\right), 54.3\left(\mathrm{OCH}_{3}\right)$, $114.0(\mathrm{CH}), 121.9(\mathrm{CH}), 125.7(\mathrm{CH}), 129.3(\mathrm{CH}), 130.1$ $(\mathrm{CH}), 131.2(\mathrm{C}), 135.0(\mathrm{C}), 149.2(\mathrm{C})$.

Compound (4p): White solid, mp $104^{\circ} \mathrm{C} ;{ }^{1} \mathrm{H}$ NMR $\left(400 \mathrm{MHz}, \mathrm{CDCl}_{3}\right): \delta=1.33-1.50(\mathrm{~m}, 6 \mathrm{H}), 1.54-2.10$ $(4 \mathrm{H}, \mathrm{m}), 3.64(\mathrm{~d}, J=10.4 \mathrm{~Hz}, 3 \mathrm{H}), 3.66(\mathrm{~d}, J=$ $10.4 \mathrm{~Hz}, 3 \mathrm{H}), 4.84$ (br s, $1 \mathrm{H}), 7.00$ (t, $J=7.1 \mathrm{~Hz}, 1 \mathrm{H}$ ),

Table 1. Effect of different PFPAT and solvents on formation of 4 .

\begin{tabular}{lccc}
\hline Entry & $\begin{array}{c}\text { PFPAT } \\
\text { amount } \\
(\text { mol \% })\end{array}$ & Condition/solvent & $\begin{array}{c}\text { Time (h)/ } \\
\text { yield }\end{array}$ \\
\hline 1 & 0 & r.t/ $\mathrm{CH}_{3} \mathrm{CN}$ & $12 / 0$ \\
2 & 5 & r.t/ $\mathrm{CH}_{3} \mathrm{CN}$ & $5 / 60$ \\
3 & 10 & r.t $/ \mathrm{CH}_{3} \mathrm{CN}$ & $1 / 90$ \\
4 & 10 & r.t/ toluene & $8 / 50$ \\
5 & 10 & r.t/ $\mathrm{CH}_{2} \mathrm{Cl}_{2}$ & $5 / 65$ \\
6 & 10 & r.t/THF & $5 / 55$ \\
7 & 10 & r.t/ethanol & $3 / 60$ \\
8 & 10 & r.t/ $/ \mathrm{H}_{2} \mathrm{O}$ & $5 / 20$ \\
9 & 10 & r.t/diethyl ether & $8 / 10$ \\
10 & 15 & r.t $/ \mathrm{CH} \mathrm{CH}_{3} \mathrm{CN}$ & $1 / 90$ \\
\hline
\end{tabular}


$7.13(\mathrm{~d}, J=8.1 \mathrm{~Hz}, 2 \mathrm{H}), 7.16(\mathrm{t}, J=8.1 \mathrm{~Hz}, 2 \mathrm{H}) .{ }^{13} \mathrm{C}$ NMR $\left(100 \mathrm{MHz}, \mathrm{CDCl}_{3}\right): d=19.7\left(\mathrm{CH}_{2}\right), 25.6\left(\mathrm{CH}_{2}\right)$, $25.1\left(\mathrm{CH}_{2}\right), 52.2\left(\mathrm{~d},{ }^{2} J_{\mathrm{P}-\mathrm{C}}=7.4 \mathrm{~Hz}, \mathrm{OCH}_{3}\right), 53.2(\mathrm{~d}$, $\left.{ }^{2} J_{\mathrm{P}-\mathrm{C}}=7.4 \mathrm{~Hz}, \mathrm{OCH}_{3}\right), 65.2\left(\mathrm{~d}, J_{\mathrm{P}-\mathrm{C}}=155.1 \mathrm{~Hz}, \mathrm{C}\right)$, $118.2(\mathrm{CH}), 118.3(\mathrm{CH}), 129.1(\mathrm{CH}), 145.5(\mathrm{C})$.

\section{Results and discussion}

In order to optimize the reaction conditions, we chose the condensation of the reaction of benzaldehyde, aniline and dimethyl phosphite catalysed by PFPAT under different conditions both in the absence and in the presence of PFPAT and results are given in table 1.

It is noteworthy that in the absence of catalyst, no product formation was observed even after long reaction times (table 1, entry 1). Then, the effect of temperature, the amount of catalyst, and the reaction time on the yield of the product were examined. It was found that this condensation reaction was affected by various solvents (table 1, entries 3-9). Among them, acetonitrile provided the highest yield at room temperature

Table 2. PFPAT-Catalyzed one-pot synthesis of $\alpha$-amino phosphonate derivatives.

\begin{tabular}{|c|c|c|c|c|c|}
\hline Entry & Aldehyde/Ketone & Amine & Time (min) & Product & Yield (\%) \\
\hline 1 & & & 60 & $4 a$ & 90 \\
\hline 2 & & & 60 & $4 b$ & 95 \\
\hline 3 & & & 60 & $4 c$ & 95 \\
\hline 4 & & & 90 & $4 d$ & 85 \\
\hline 5 & & & 60 & $4 e$ & 95 \\
\hline 6 & & & 120 & $4 f$ & 80 \\
\hline 7 & & & 120 & $4 \mathrm{~g}$ & 80 \\
\hline 8 & & & 100 & $4 h$ & 85 \\
\hline 9 & & & 90 & $4 \mathbf{i}$ & 88 \\
\hline 10 & & & 90 & $4 \mathbf{j}$ & 90 \\
\hline 11 & & & 120 & $4 k$ & 85 \\
\hline 12 & & & 60 & 41 & 90 \\
\hline 13 & & & 70 & $4 m$ & 85 \\
\hline 14 & & & 60 & $4 n$ & 90 \\
\hline 15 & & & 60 & 40 & 85 \\
\hline 16 & & & 120 & $4 p$ & 80 \\
\hline 17 & & & 120 & $\mathbf{4 q}$ & 80 \\
\hline
\end{tabular}


after $1 \mathrm{~h}$ (table 1, entry 3 ). Then, we examined the optimal amount of catalyst using the same model reaction (table 1, entries 1-3). We observed that $10 \mathrm{~mol} \%$ of PFPAT was sufficient to catalyse the reaction smoothly. Increasing either the amount of catalyst and/or prolonging the reaction time did not improve the yield (table 1, entry 10), while reducing these factors led to a reduction in product yield (table 1, entry 2 ).

Having optimized the reaction conditions, the scope and efficiency of this approach was explored for the synthesis of a wide variety of substituted $\alpha$-amino phosphonate and results are summarized in table 2 .

A wide range of structurally varied aldehyde reacted smoothly and quickly to give the corresponding $\alpha$ amino phosphonate in high yield and purity as listed in table 2. In all cases, aromatic aldehydes substituted with either electron-donating or electron-withdrawing groups underwent the reaction smoothly and gave the products in good yields. It could also be concluded that the aldehydes bearing electron-withdrawing groups required shorter time and gave higher yields (table 1 , entries 2 and 3). This method is even effective with aliphatic aldehydes, which normally produce low yields due to their intrinsic lower reactivity. In addition, when $\alpha, \beta$-unsaturated aldehydes reacted with aniline and dimethyl phosphite in acetonitrile in the presence of PFPAT, a longer reaction time was required for the reaction to be completed and to give the 1,2-addition products in high yields (table 2, entry 4). This method is also effective with ketones. No $\alpha$-hydroxy phosphonate (an adduct between an aldehyde and dimethyl phosphite) was obtained under these reaction conditions. This is due to rapid formation and activation of the imines or iminium salts by PFAPT. Moreover, the highly hydrophobic pentafluorophenyl moiety effectively repels $\mathrm{H}_{2} \mathrm{O}$ produced by the dehydration steps.

Arylamines with electron-donating substituents such as alkyl and methoxyl groups and with weak electronwithdrawing groups such as chloro and bromo all gave good yields of products.

In addition, the PFPAT catalyst was easily removed from the reaction mixture after work-up, by washing with an aqueous $\mathrm{NaOH}$ solution to remove the $\mathrm{CF}_{3} \mathrm{SO}_{3} \mathrm{H}$, followed by distillation under reduced pressure $\left(\mathrm{C}_{6} \mathrm{~F}_{5} \mathrm{NH}_{2}\right.$ : bp $153^{\circ} \mathrm{C}$ at $\left.760 \mathrm{mmHg}\right){ }^{42}$

\section{Conclusion}

In conclusion, we have developed an efficient synthesis of $\alpha$-aminophosphonate derivatives via the onepot three-component coupling reaction of aldehydes, amines and dimethyl phosphite under mild conditions using PFPAT as an efficient organocatalyst. In contrast to the existing methods using potentially hazardous catalysts/additives, the present method offers the following competitive advantages: PFPAT is easy-to prepare from commercially available pentafluoroaniline and triflic acid; short reaction time; ease of product isolation/purification by non-aqueous work-up; absence of side reaction; low cost and simplicity in process and handling; and an environmentally benign process.

\section{Supplementary information}

Supplementary data associated with this article synthesis and NMR spectra can be found in the online version (ww.ias.ac.in/chemsci).

\section{Acknowledgement}

This research is supported by the Islamic Azad University, Ayatollah Amoli Branch.

\section{References}

1. Bartlett P A, Hanson J E and Giannousis P P 1990 J. Org. Chem. 556268

2. Kafarski P and Lejczak B 1991 Phosphorus Sulfur Silicon Relat. Elem. 63193

3. Allen M C, Fuhrer W, Tuck B, Wade R and Wood J M 1989 J. Med. Chem. 321652

4. Logusch E W, Walker D M, McDonald J F, Leo G C and Franz J E 1988 J. Org. Chem. 534069

5. Giannousis P P and Bartlett P A 1987 J. Med. Chem. 30 1603

6. Peyman A, Budt K H, Spanig J, Stowasser B and Ruppert D 1992 Tetrahedron Lett. 334549

7. Stowasser B, Budt K H, Jian-Qi I, Peyman A and Ruppert D 1992 Tetrahedron Lett. 336625

8. Natchev I A 1988 Liebigs Ann. Chem. 861

9. Emsley J and Hall D 1976 The chemistry of phosphorus (London: Harper and Row) p. 494

10. Maier L and Spörri H 1991 Phosphorus Sulfur Silicon Relat. Elem. 6169

11. Huang J and Chen R 2000 Heteroatom Chem. 11480

12. Smith A B, Taylor C M, Benkovic S J and Hirschmann R 1994 Tetrahedron Lett. 356853

13. Kim D Y and Yong Rhie D 1997 Tetrahedron 5313603

14. Afarinkia K, Cadogan J I G and Rees C W 1990 Synlett 415

15. Yuan C, Chen S and Wang G 1991 Synthesis 490

16. Sasai H, Shigeru A, Tahara Y and Shibasaki M 1995 J. Org. Chem. 606656

17. Laschat S and Kunz H 1992 Synthesis 90

18. Manjula A, Vittal R B and Parvathi N 2003 Synth. Commun. 332963

19. Genet J P, Uziel J, Port M, Touzin S, Roland A M, Thorimbert S and Tanier S 1992 Tetrahedron Lett. 3377

20. Laschat S and Kunz H 1992 Synthesis 90 
21. Pudovik A N 1952 Dokl. Akad. Nauk SSSR 83 865; 1953 Chem. Abstr. 474300

22. Petrov K A, Chauzov V A and Erkhina T S 1974 Usp. Khim. 43 2045; 1975 Chem. Abstr. 82449

23. Manjula A, Rao V and Neelakanthan P 2003 Synth. Commun. 332963

24. Yadav J S, Reddy B V S, Raj S, Reddy K B and Prasad A R 2001 Synthesis 22

25. Zon J 1981 Pol. J. Chem. 55643

26. Ha H J and Nam G S 1992 Synth. Commun. 221143

27. Heydari A, Hamadi H and Pourayoubi M 2007 Catal. Commun. 81224

28. Bhagat S and Chakraborti A K 2007 J. Org. Chem. 72 1263

29. Heydari A and Arefi A 2007 Catal. Commun. 81023

30. Bhattacharya A K and Kaur T 2007 Synlett 745

31. Qian C and Huang T 1998 J. Org. Chem. 634125

32. Ranu B C, Hajra A and Jana J 1999 Org. Lett. 11141

33. Firouzabadi H, Iranpoor N and Sobhani S 2004 Synthesis 2692

34. Heydari A, Karimian A and Ipaktschi J 1998 Tetrahedron Lett. 396729

35. Kaboudin B and Nazari R 2001 Tetrahedron Lett. 42 8211

36. Akiyama T, Sanada M and Fuchibe K 2003 Synlett 1463

37. Yadav J S, Reddy B V S and Madan C 2001 Synlett 1131

38. Kudrimoti S and Bommena Roa V 2005 Tetrahedron Lett. 461209

39. Qian C and Huang T 1998 J. Org. Chem. 634125

40. Ranu B C, Hajra A and Jana U 1999 Org. Lett. 11141

41. Chandrasekhar S, Prakash S J, Jagadeswar V and Narsihmulu C 2001 Tetrahedron Lett. 425561
42. Vahdat S M, Baharfar R, Tajbakhsh M, Heydari A, Baghbanian S M and Khaksar S 2008 Tetrahedron Lett. 496501

43. Heydari A, Khaksar S and Tajbakhsh M 2009 Tetrahedron Lett. $\mathbf{5 0} 77$

44. Hazeri N, Maghsoodlou M T, Habibi-Khorassani S M, Aboonajmi J, Lashkari M and Sajadikhah S S 2014 Res. Chem. Intermed. 401781

45. List B 2007 Chem. Rev. 1075413

46. Schreiner P R 2003 Chem. Soc. Rev. 32289

47. Doyle A G and Jacobsen E N 2007 Chem. Rev. 107 5713

48. Dalko P I and Moisan L 2004 Angew. Chem., Int. Ed. 43 5138

49. Funatomi T, Wakasugi K, Misaki T and Tanabe Y 2006 Green Chem. 81022

50. Iida A, Osada J, Nagase R, Misaki T and Tanabe Y 2007 Org. Lett. 91859

51. Nagase R, Osada J, Tamagaki H and Tanabe Y $2010 A d v$. Synth. Catal. 3521128

52. Khaksar S, Vahdat S M and Rezaee F 2013 C R Chim. 16144

53. Khaksar S and Behzadi N 2012 Comb. Chem. High T. Scr. 15845

54. Khaksar S and Ostad S M 2011 J. Fluorine Chem. 132 937

55. Khaksar S, Fattahi E and Fattahi E 2011 Tetrahedron Lett. 525943

56. Khaksar S, Vahdat S M and Moghaddamnejad R N 2012 Monatsh. Chem. 1431671

57. Khaksar S, Vahdat S M, Tajbakhsh M, Jahani F and Heydari A 2010 Tetrahedron Lett. 516388 